\title{
PCR-SSCP: A Method for the Molecular Analysis of Genetic Diseases
}

\author{
K. V. Kakavas $\cdot$ P. Plageras $\cdot$ A. T. Vlachos $\cdot$
}

A. Papaioannou $\cdot$ A. V. Noulas

Published online: 25 June 2008

(C) Humana Press 2008

Erratum to: Mol Biotechnol (2007)

DOI 10.1007/s12033-007-9006-7

The authors' surnames were incorrectly captured. The correct surnames are Kakavas V.K., Plageras P., Vlachos T.A., Papaioannou A., Noulas V.A.

The online version of the original article can be found at doi: 10.1007/s12033-007-9006-7.

K. V. Kakavas $(\square)$. P. Plageras · A. T. Vlachos ·

A. Papaioannou $\cdot$ A. V. Noulas

Laboratory of Clinical Chemistry, School of Medical

Laboratories, Faculty of Health and Care, Highest Technological

Institute of Larissa, 37 Xenopulu str, Larissa 41221, Greece

e-mail: flokakavas@sch.gr 